\title{
Serum Ferritin and Transferrin Saturation with Anemia in Patients of Chronic Kidney Disease at a Tertiary Care Teaching Hospital
}

\author{
Rajesh Kumar ${ }^{1}$, Naresh Kumar ${ }^{1}$ \\ ${ }^{1}$ Associate Professor, Department of Medicine, \\ Rama Medical College Hospital \& Research Centre, Hapur, Uttar Pradesh, India.
}

\begin{abstract}
Objectives: Present study was conducted to estimate serum ferritin (a measure of storage iron); and transferrin saturation (a measure of current iron supply to tissues) levels in patients of chronic kidney disease (CKD).

Methods: Present study was a prospective study conducted among patients suffering from CKD and admitted in Rama Medical College Hospital \& Research Centre, Hapur, Uttar Pradesh (India). 60 cases of CKD were selected on the basis of simple random sampling method. All patient data was collected through history, physical examination and laboratory investigation.
\end{abstract}

Results: In the study group of 60 patients with CKD, maximum incidence of $26(43.3 \%)$ patients seen in age group of 51 $60 y e a r s . ~ P a t i e n t s$ age ranged from 29-81 years. In the study group of 60 patients of CKD, $46(76.7 \%)$ were males and 14 $(23.3 \%)$ were females. Male:female ratio was $3.29: 1$. Facial puffiness was the most common symptom found in $53(88.3 \%)$ patients followed by pedal oedema in $49(81.7 \%)$ patients. Among 60 patients, $43(71.7 \%)$ patients had hypertension, followed by diabetes mellitus in $39(65 \%)$ patients. Combination of both diseases seen in 28 (46.7\%) patients.

Among 60 Patients of CKD studied, $48.3 \%$ of patients had haemoglobin percentage of $8.1-9 \mathrm{gm} \%$, followed by $31.7 \%$ of patients in the range of $9.1-10 \mathrm{gm} \%$. Haemoglobin percentage is ranged from $6.1-11 \mathrm{gm} \%$. All of them belong to stage V CKD according to Cockcroft Gault formula. Among 60 patients studied, 27(45.0\%) patients had Blood Urea level between $101-150$ followed by $21(35.0 \%)$ of patients in the range of 151 200. $91.7 \%$ patients had S. Creatinine level between 5-14.9.

\section{INTRODUCTION}

Chronic kidney disease (CKD), also known as chronic renal disease, is characterized by irreversible deterioration of renal function, which results from diminished effective functioning of renal tissue. Anemia is a common complication associated with chronic kidney disease. The prevalence of anemia varies with the degree of renal impairment in pre dialysis patients with CKD, but once end-stage kidney failure occurs, all patients are eventually affected. Anemia reduces physical capacity, well-being, neurocognitive function, and energy level and worsens quality of life. Absolute or functional iron deficiency is present in $25-38 \%$ of patients with anemia of CKD. ${ }^{1-4}$

The National Kidney Foundation (NKF-K/DOQI) Clinical Practice Guidelines recommend an evaluation of anemia among patients
Among 60 Patients of CKD studied, 16 (26.7\%) patients had S. ferritin less than 100ug \% followed by $11(16.7 \%)$ patients had between 101-200ug. Mean $S$ ferritin of total patients was 179.3 \pm 31.03 . 26(43.3\%) patients had transferrin saturation level $<20 \mathrm{ug} \%$ followed by $23(38.3 \%)$ patients $>20 \mathrm{ug} \%$ to $<40$ $\mathrm{ug} \%$ and $11(18.3 \%)$ patients is above $40 \mathrm{ug} \%$. Mean transferrin saturation was $17.1 \pm 5.9$.

Conclusion: Serum ferritin and transferrin saturation are the primary tools for assessing iron status and management in patients with anaemia of CKD patients. These biochemical parameters helps in diagnosis and treatment of iron deficiency in CKD.

Keywords: Chronic Kidney Disease, Blood Urea, Serum Ferritin, Serum Transferrin Saturation, Serum Creatinine.

\section{*Correspondence to:}

\section{Dr. Rajesh Kumar,}

Associate Professor, Department of Medicine,

Rama Medical College Hospital \& Research Centre,

Hapur, Uttar Pradesh, India.

\section{Article History:}

Received: 18-05-2016, Revised: 27-05-2016, Accepted: 20-06-2016

\begin{tabular}{|l|c|}
\hline \multicolumn{2}{|c|}{ Access this article online } \\
\hline $\begin{array}{l}\text { Website: } \\
\text { www.jjmrp.com }\end{array}$ & Quick Response code \\
\hline DOI: & \\
10.21276/jmrp.2016.2.4.032 & \\
\hline
\end{tabular}

with renal insufficiency when the hemoglobin is _ $11 \mathrm{~g} / \mathrm{dl}$ among premenopausal women and _12 g/dl among adult men and postmenopausal women. Epoetin treatment is recommended for patients with $\mathrm{CRI}$, whether dialysis dependent or not, to achieve a target hemoglobin of 11 to $12 \mathrm{~g} / \mathrm{dl} .{ }^{5}$ Similar guidelines have been put forth by the European Renal Association/European Dialysis and Transplantation Association. ${ }^{6}$

Serum ferritin and transferrin saturation (TSAT) are the standard laboratory tests to evaluate iron stores, and the limits for diagnosis of iron deficiency and adequate iron in healthy adults are fairly well defined.

Serum ferritin and transferrin saturation (TSAT) are routinely utilized in dialysis patients to aid in diagnosing iron deficiency and 
in guiding iron therapy. Uniformly low TSAT $(<20 \%)$ and ferritin $(<200 \mathrm{ng} / \mathrm{ml})$ are clear indicators of iron deficiency and predict a higher likelihood of response to i.v. iron. ${ }^{7}$ However, ferritin and TSAT values are frequently discordant, as they are, respectively, positive and negative acute phase reactants. ${ }^{8}$ Consequently, in the setting of inflammation or malnutrition, simultaneously high ferritin and low TSAT are frequently encountered and difficult to evaluate. $^{7}$

Present study was conducted to estimate serum ferritin (a measure of storage iron ${ }^{9}$ ); and transferrin saturation (a measure of current iron supply to tissues ${ }^{9}$ ) levels in patients of CKD.

\section{METHODS}

Present study was a prospective study conducted among patients suffering from CKD and admitted in Rama Medical College Hospital \& Research Centre, Hapur, Uttar Pradesh (India). 60 cases of CKD were selected on the basis of simple random sampling method. Informed consent was taken prior to study from all participants. Study protocol was approved by Institutional ethics committee. A Structured questionnaire was used to collect data about sociodemographic, clinical and laboratory parameters. All the patients underwent detailed, clinical examination and the following investigations were carried out; $\mathrm{Hb} \%$, Complete hemogram, Fasting blood sugar, post prandial blood sugar, blood urea, serum creatinine, Serum electrolytes, Urine routine; albumin, Sugar, microscopy, Ultra sound abdomen, ECG, Fasting Lipid Profile, HIV 1\&2, anti-HCV, HbsAg, Serum Iron, Serum Ferritin, tranferrin Saturation. Blood samples are drawn for Serum Ferritin concentration and measured by Chemilumiscence method. Transferrin saturation level calculated using formula Transferrin Saturation $=$ Serum Iron $/ \mathrm{TIBC} .{ }^{10}$

Absolute Iron deficiency is defined as serum ferritin $<100 \mathrm{ng} / \mathrm{ml}$ in non-dialysis dependent CKD and patients treated with peritoneal dialysis and $<200 \mathrm{ng} / \mathrm{ml}$ in hemodialysis patients. Functional iron deficiency is diagnosed when serum ferritin is 100 $200 \% \mathrm{ng} / \mathrm{ml}$. Transferrin saturation is $<20 \%$ indicates iron deficiency in all patients. ${ }^{10,11}$

\section{RESULTS}

In the study group of 60 patients with CKD, maximum incidence of $26(43.3 \%)$ patients seen in age group of 51-60years. Patients age ranged from 29-81 years. In the study group of 60 patients of CKD, 46 (76.7\%) were males and 14 (23.3\%) were females. Male:female ratio was $3.29: 1$. Facial puffiness was the most common symptom found in $53(88.3 \%)$ patients followed by pedal oedema in $49(81.7 \%)$ patients. Among 60 patients, 43 (71.7\%) patients had hypertension, followed by diabetes mellitus in 39 $(65 \%)$ patients. Combination of both diseases seen in $28(46.7 \%)$ patients. (Table 1)

Among 60 Patients of CKD studied, $48.3 \%$ of patients had haemoglobin percentage of $8.1-9 \mathrm{gm} \%$, followed by $31.7 \%$ of patients in the range of $9.1-10 \mathrm{gm} \%$. Haemoglobin percentage is ranged from $6.1-11 \mathrm{gm} \%$. All of them belong to stage $V$ CKD according to Cockcroft Gault formula. (Table 2)

Table 1: Details of study population.

\begin{tabular}{llcc}
\hline & & Number of Patients & Percentage \\
\hline Age (Years) & $\leq 40$ & 4 & 6.7 \\
& $41-50$ & 7 & 11.7 \\
S1-60 & 26 & 43.3 \\
Gender & $61-70$ & 19 & 31.7 \\
& $\geq 71$ & 4 & 6.7 \\
Symptoms & Total & 60 & 100 \\
& Male & 46 & 76.7 \\
Female & 14 & 23.3 \\
& Total & 60 & 100 \\
& Facial puffiness & 53 & 88.3 \\
& Pedal oedema & 49 & 81.7 \\
& Easy fatiguability & 41 & 68.3 \\
& Breathlessness & 21 & 35.0 \\
& Decreased urine output & 19 & 31.7 \\
& Altered sensorium & 7 & 11.7 \\
& HTN & 43 & 71.7 \\
& DM & 39 & 65 \\
& HHD & 19 & 31.7 \\
& Dyslipidemia & 10 & 16.7 \\
& DM, HTN & 28 & 46.7 \\
& DM, HTN, IHD & 9 & 15 \\
\hline
\end{tabular}


Table 2: Stage of kidney based on GFR correlation with $\mathrm{Hb}$ percentage

\begin{tabular}{lccc}
\hline $\mathrm{Hb} \%$ & No. of Patients & Percentage & Stage of CKD \\
\hline $6.1-7$ & 2 & 3.3 & Stage of $\mathrm{V}$ \\
$7.1-8$ & 5 & 8.3 & Stage of $\mathrm{V}$ \\
$8.1-9$ & 29 & 48.3 & Stage of $\mathrm{V}$ \\
$9.1-10$ & 19 & 31.7 & Stage of $\mathrm{V}$ \\
$10.1-11$ & 5 & 8.3 & Stage of $\mathrm{V}$ \\
Total & 60 & 100 & Stage of $\mathrm{V}$ \\
\hline
\end{tabular}

Table 3: Distribution of Blood Urea \& Serum creatinine in CKD

\begin{tabular}{llcc}
\hline & & Number of patients & Percentage \\
\hline B. Urea level & $\leq 100$ & 2 & 3.3 \\
& $101-150$ & 27 & 45.0 \\
& $151-200$ & 21 & 35.0 \\
& $201-250$ & 7 & 11.7 \\
& $251-300$ & 1 & 1.7 \\
& $\geq 301$ & 2 & 3.3 \\
Serum & Total & 60 & 100 \\
creatinine & $0-4.9$ & 3 & 5 \\
& $5-9.9$ & 32 & 53.3 \\
& $10-14.9$ & 23 & 38.3 \\
& $\geq 15$ & 2 & 3.3 \\
& Total & 60 & 100 \\
\hline
\end{tabular}

Table 4: Distribution of S. ferritin \& Transferrin saturation in CKD patients

\begin{tabular}{llcc}
\hline & & Number of patients & Percentage \\
\hline Serum & $\leq 100$ & 16 & 26.7 \\
ferritin & $101-200$ & 11 & 16.7 \\
& $201-300$ & 25 & 41.7 \\
& $\geq 301$ & 08 & 13.3 \\
& Total & 60 & 100 \\
TSAT\% & $\leq 10$ & 3 & 5 \\
& $10.1-20$ & 23 & 38.3 \\
& $20.1-30$ & 10 & 16.7 \\
& $30.1-40$ & 13 & 21.7 \\
& $\geq 40.1$ & 11 & 18.3 \\
& Total & 60 & 100 \\
\hline
\end{tabular}

Among 60 patients studied, 27(45.0\%) patients had Blood Urea level between 101-150 followed by $21(35.0 \%)$ of patients in the range of 151-200. 55 (91.7\%) patients had S. Creatinine level between 5-14.9. (Table 3)

Among 60 Patients of CKD studied, 16 (26.7\%) patients had S. ferritin less than 100ug \% followed by $11(16.7 \%)$ patients had between 101-200ug. Mean $S$ ferritin of total patients was $179.3 \pm 31.03$.

$26(43.3 \%)$ patients had transferrin saturation level $<20 \mathrm{ug} \%$ followed by $23(38.3 \%)$ patients $>20 \mathrm{ug} \%$ to $<40 \mathrm{ug} \%$ and 11 $(18.3 \%)$ patients is above $40 \mathrm{ug} \%$. Mean transferrin saturation was 17.1 \pm 5.9 . (Table 4)

\section{DISCUSSION}

In the study group of 60 patients of CKD, $46(76.7 \%)$ were males and $14(23.3 \%)$ were females. Male:female ratio was 3.29:1. Previous researchers also demonstrated similar findings like Rajashekar S et al., Avasthi et al., Alam SM et al., Altaf Basha et al. ${ }^{10,12-14}$ As men suffer CKD more than females according to present study, this can be due that men tend to seek medical attention more than females.

Maximum incidence of 26 (43.3\%) patients were seen in age group of 51-60years in present study. It can be concluded that increasing age is a risk factor of CKD as age increases, GFR decreases. Therefore CKD is common in elderly than young 
individuals. Hypertension and diabetes were the main underlying diseases for CKD individually.

Among 60 Patients of CKD studied, $48.3 \%$ of patients had haemoglobin percentage of $8.1-9 \mathrm{gm} \%$, followed by $31.7 \%$ of patients in the range of $9.1-10 \mathrm{gm} \%$. Haemoglobin percentage is ranged from $6.1-11 \mathrm{gm} \%$; which is comparable with previous studies. ${ }^{15,16}$ Mean S. ferritin is $179.3 \pm 31.03$ and transferrin saturation is $17.1 \pm 5.9$ respectively. Which is comparable with Silverberg et al., Raveendra N. Mudiyammanavara et al and Rajashekhar et al. ${ }^{10,16,17}$

Anemia develops once renal function decreases to $50 \%$ because of a deficiency in endogenous erythropoietin production by the kidney, decreased red cell survival, blood losses, and increased red blood cell destruction once the patient begins dialysis treatment, particularly hemodialysis. 18

The observation that patients with endstage renal disease appear to have a "functional iron deficiency" led us to hypothesize that not only were iron deficiency and renal insufficiency both independent risk factors for anemia, but there might be an interaction. The same degree of iron deficiency might be associated with a greater drop in hemoglobin in patients with reduced renal function than in patients with preserved renal function. ${ }^{5}$

\section{CONCLUSION}

Serum ferritin and transferrin saturation are the primary tools for assessing iron status and management in patients with anaemia of CKD patients. These biochemical parameters help in diagnosis and treatment of iron deficiency in CKD.

\section{REFERENCES}

1. Strippoli GFH, Craig JC, Manno C, Schena FP. Hemoglobin targets for the anemia of chronic kidney disease: A meta-analysis of randomized, controlled trials. J Am SocNephrol 2004; 15: 315465.

2. Hsu CY, McCulloch CE, Curhan GC, Epidemiology of anemia associated with chronic renal insufficiency among adults in the United States: Results from the Third National Health and Nutrition Exmination Survey. J Am SocNephrol 2002; 13: 504-10.

3. Obrador GT, Roberts T, St Peter WL, Frazier E, Pereira BJ, Collins AJ, Trends in anemia at initiation of dialysis in the United States. Kidney Int 2001; 60: 1875-84.

4. Hemodialysis. Australia and New Zealand Registry Annual Report. 2001.

5. National Kidney Foundation NKF-K/DOQI clinical practice guidelines for anemia of chronic kidney disease: Update 2000. Am J Kidney Dis 2001;37[Suppl 1]: S182-S238

6. European best practice guidelines for the management of anemia in patients with chronic renal failure. Nephrol Dial Transplant 14[Suppl 5]: 5-13, 1999.

7. KDOQI Clinical Practice Guidelines and Clinical Practice. Recommendations for anemia in chronic kidney disease. Am J Kidney Dis 2006; 47: S11-S145.

8. Coyne DW. Iron indices: what do they really mean? Kidney Int 2006; 101: S4-S8.
9. Brittenham GM: Disorders of iron metabolism: Iron deficiency and overload. In: Hematology: Basic Principles and Practice, 3rd Ed., edited by Hoffman R, Benz EJ, Shattil SJ, Furie B, Cohen HJ, Silberstein LE, et al. New York, Churchill Livingstone, 2000, pp 397-428.

10. Rajashekar S. A Study of Serum Ferritin and Transferrin Saturation in Patients with Anemia in Chronic Kidney Disease. Journal of Evolution of Medical and Dental Sciences 2014; 3(67), December 04; Page: 14502-14509, DOI: 10.14260/jemds/2014/3945

11. Mann JF. What are the short-term and long-term consequences of anemia in CRF patients? Nephrol Dial Transplant 1999; 14 (2): 29-36.

12. Avasthi G, Mittal D, Soni GL. Lipid profile of patients of chronic renal failure. Indian J Med Res 1986;84:612-6.

13. Alam SM, Bhatt AK. Abnormal lipoprotein in uraemic patients treated conservatively and by maintenance hemodialysis. JAPI 1991;39(2): 170-1.

14. Basha SA, Singh DS, Kotiyal JP, Bisht DB. Study of lipid profile and alimentary lipemia in chronic renal failure. J AssocPhys India 1979;27:1079-83.

15. Talwar UK, Gupta HL, Narayana S. Clinical haematological profile in chronic renal failure. J Assoc Physicians India 2002 Feb;50:228-33.

16. Raveendra N. Mudiyammanavara, Dhananjaya P.E., Rajeev Agarwal. Cross sectional study of anaemia in chronic kidney disease. Indian Journal of Basic and Applied Medical Research; March 2015: Vol.-4, Issue- 2, P. 414-419.

17. Silverberg DS, Wexler D, Blum M, Keren G, Sheps D, Leibovitch $E$, et al. The Use of subcutaneous erythropoietin and intravenous iron for the treatment of the anemia of severe, resistant congestive heart failure improves cardiac and renal function and functional cardiac class, and markedly reduces hospitalizations. JACC 2000;35(7):1737-44.

18. Caro J, Brown S, Miller O, Murray T, Erslev AJ. Erythropoietin levels in uremic nephric and anephric patients. J Lab Clin Med 1979; 93: 449-58.

\section{Source of Support: Nil.}

Conflict of Interest: None Declared.

Copyright: () the author(s) and publisher. IJMRP is an official publication of Ibn Sina Academy of Medieval Medicine \& Sciences, registered in 2001 under Indian Trusts Act, 1882.

This is an open access article distributed under the terms of the Creative Commons Attribution Non-commercial License, which permits unrestricted non-commercial use, distribution, and reproduction in any medium, provided the original work is properly cited.

Cite this article as: Rajesh Kumar, Naresh Kumar. Serum Ferritin and Transferrin Saturation with Anemia in Patients of Chronic Kidney Disease at a Tertiary Care Teaching Hospital. Int J Med Res Prof. 2016; 2(4):135-38. 